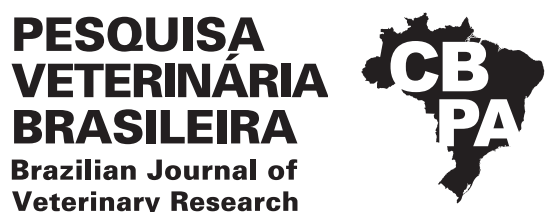

Pesq. Vet. Bras. 40(5):385-388, May 2020 DOI: 10.1590/1678-5150-PVB-6521

Original Article

Veterinarv Research

ISSN 0100-736X (Print)

Livestock Diseases

ISSN 1678-5150 (Online)

\title{
Performance of the Dot-blot test method for detecting antibodies to Sarcocystis spp. in cattle ${ }^{1}$
}

\author{
Maiara S.T. Ferreira ${ }^{2}$, Fagner D. Fernandes ${ }^{2 *}$ (D) Marta E.M. Alves ${ }^{2}$, \\ Patricia Bräunig ${ }^{2}$, Luis A. Sangioni ${ }^{2}$ and Fernanda S.F. Vogel ${ }^{2}$
}

\begin{abstract}
Ferreira, M.S.T., Fernandes F.D., Alves, M.E.M, Braunig P., Sangioni, L.A. \& Vogel F.S.F. 2020. Performance of the Dot-blot test method for detecting antibodies to Sarcocystis spp. in cattle. Pesquisa Veterinária Brasileira 40(5):385-388. Departamento de Medicina Veterinária Preventiva, Universidade Federal de Santa Maria, Avenida Roraima 1000, Santa Maria, RS 97105-900, Brazil. E-mail: fagnermedvet@gmail.com

Serological techniques can detect antibodies against Sarcocystis spp., Neospora caninum and Toxoplasma gondii antigens in single or mixed infections. Immunofluorescent antibody tests (IFAT) is considered the gold standard technique for Sarcocystosis diagnostic in cattle serum and a positive IFAT result reflects Sarcocystis spp. infection. Therefore, the aims of the present study were to compare IFAT and Dot-blot for sarcocystosis diagnostic in experimentally infected mice and to investigate serological cross-reactions with $N$. caninum and T. gondii in these methods. Mice (Mus musculus) were inoculated intraperitoneally with bradizoites of Sarcocystis spp. or tachyzoites of N. caninum or T. gondii. Serum samples were obtained and analyzed by IFAT and Dot-blot for the three protozoa. Serum from N. caninum and T. gondii experimentally infected mice were tested by IFAT and reacted only to $N$. caninum or T. gondii antigens, respectively. Specific antibodies against Sarcocystis spp. were present in all animals experimentally infected with this protozoan, with IFAT titers from 10 to 800. Serum samples from mice experimentally infected with Sarcocystis spp., N. caninum and T. gondii and tested by Dot-blot demonstrated no cross reaction between protozoa. A Dot-blot using Sarcocystis spp. antigen appears to be a good alternative to IFAT in the serological diagnosis of Sarcocystosis.
\end{abstract}

INDEX TERMS: Dot-blot test, antibodies, Sarcocystis spp., cattle, serological diagnosis, IFAT, protozoan.

\begin{abstract}
RESUMO.- [Desempenho do teste Dot-blot para detecção de anticorpos para Sarcocystis spp. em bovinos.] As técnicas sorológicas podem detectar anticorpos contra os antígenos de Sarcocystis spp., Neospora caninum e Toxoplasma gondii em infecções únicas ou mistas. 0 teste de anticorpos imunofluorescentes (IFAT) é considerado a técnica padrãoouro para o diagnóstico de sarcocistose no soro de bovinos e um resultado positivo de IFAT reflete Sarcocystis spp. infecção. Portanto, os objetivos do presente estudo foram comparar IFAT e Dot-blot para diagnóstico de sarcocistose em camundongos infectados experimentalmente e investigar reações cruzadas sorológicas com $N$. caninum e T. gondii nesses métodos. Os camundongos (Mus musculus) foram inoculados
\end{abstract}

\footnotetext{
${ }^{1}$ Received on December 26, 2019.

Accepted for publication on February 11, 2020.

${ }^{2}$ Departamento de Medicina Veterinária Preventiva, Universidade Federal da Santa Maria (UFSM), Av. Roraima 1000, Camobi, Santa Maria, RS 97105900, Brazil. *Corresponding author: fagnermedvet@gmail.com
}

intraperitonealmente com bradizoítos de Sarcocystis spp. ou taquizoítos de $N$. caninum ou T. gondii. As amostras de soro foram obtidas e analisadas por IFAT e Dot-blot para os três protozoários. O soro de $N$. caninum e T. gondii infectados experimentalmente foram testados por IFAT e reagiram apenas aos antígenos de N. caninum ou T. gondii, respectivamente. Anticorpos específicos contra Sarcocystis spp. estavam presentes em todos os animais experimentalmente infectados com este protozoário, com títulos de IFAT de 10 a 800 . Amostras de soro de camundongos infectados experimentalmente com Sarcocystis spp., N. caninum e T. gondii e testadas por Dotblot não demonstraram reação cruzada entre protozoários. Um Dot-blot usando Sarcocystis spp. 0 antígeno parece ser uma boa alternativa ao IFAT no diagnóstico sorológico da sarcocistose.

TERMOS DE INDEXAÇÃO: Dot-blot, anticorpos, Sarcocystis spp., bovinos, diagnóstico sorológico, IFAT, protozoário. 


\section{INTRODUCTION}

Sarcocystis spp., Neospora caninum and Toxoplasma gondii are coccidians belonging to Sarcocystidae family. They have worldwide distribution and may cause infections in ruminants inducing productive and economic losses (Tenter 1995, Dubey 2003, 2009). Although the prevalence of Sarcocystis spp. infection in cattle herds is approximately $90 \%$ to $100 \%$ in many countries, Sarcocystosis in cattle are frequently asymptomatic making difficult the diagnosis (Moré et al. 2011, Ruas et al. 2001, Akhlaghi et al. 2016).

Diagnosis of acute Sarcocystosis is difficult because, the clinical signs are uncommon, unspecific and the parasitemia is frequently low and consequently undetectable (Ndiritu et al. 1996, Dubey et al. 2016). Diagnosis of chronic Sarcocystosis is usually made by conventional laboratory methods as microscopy, immunoassays and tissue digestion (Fayer \& Dubey 1986, Gajadhar et al. 1987, Cawthorn \& Speer 1990). Several serological methods as immunofluorescent antibody tests (IFAT), enzyme linked immunosorbent assays (ELISA), and immunoblots (as Western blot and Dot-blot) have been developed for diagnosis the bovine Sarcocystosis (Moré et al. 2008). Serological techniques detect antibodies against the protozoans Sarcocystis spp., N. caninum and T. gondii antigens in single or mixed infections (Uggla et al. 1987, Dubey et al. 1996). However a specific and sensitive serological test which detects acute and chronic infection and suitable for screening a large number of animals is lacking for Sarcocystis spp.

The aims of the present study were a) to compare two serological tests (IFAT and Dot-blot) for Sarcocystosis diagnostic, and b) to check the cross-reactions of $N$. caninum and $T$. gondii using IFAT and Dot-blot in serum of experimentally infected mice.

\section{MATERIALS AND METHODS}

Animal inoculation and serum samples. Seven mice (Mus musculus), male, approximately 6 weeks of age with initial weight of $30 \mathrm{~g}$, without previous contact with parasites were used to obtain hyperimmune serum against Sarcocystis spp., Neospora caninum and Toxoplasma gondii. Two animals were inoculated intraperitoneally with $2 \times 10^{5}$ bradyzoites of Sarcocystis spp. obtained from cysts of a naturally infected bovine heart and purified by previously described by García-Lunar et al. (2015). Similarly, two animals were inoculated intraperitoneally with $2 \times 10^{5}$ tachyzoites of $N$. caninum and two animals with T. gondii. Parasites were obtained from culture in VERO cells as described in the item 2.2. After 20 days of infection, blood was collected from cardiac puncture and serum was obtained. One naive animal was used as a negative experimental control. Samples were identified and stored at $-20^{\circ} \mathrm{C}$ until processing.

Antigens preparation of sorological tests. Tachyzoites from the NC-1 strain of N. caninum (Dubey et al. 1988) and RH-strain of T. gondii (Sabin, 1941) were cultured in VERO cells (African green monkey kidney cells) in RPMI 1640 culture medium (Invitrogen, Brazil), supplemented with $10 \%$ fetal bovine serum (Nutricell, Brazil) with $5 \% \mathrm{CO}_{2}$ at $37^{\circ} \mathrm{C}$. Tachyzoites from $N$. caninum were obtained after cellular suspension and disruption, and solution was decanted during 30 minutes, at $4^{\circ} \mathrm{C}$, in sterile tube to diminish cell debris. Tachyzoites from T. gondii were obtained from frozen aliquots and supplemented with RPMI and fetal serum. Supernatant was recovered from each suspension and centrifuged at $1.500 \mathrm{xg}$ for 10 minutes. Tachyzoites were counted using Neubauer's chamber and re-diluted with RPMI to a final concentration of $2 \times 10^{5}$ tachyzoites $/ \mathrm{mL}$. The pellets were stored at $-80^{\circ} \mathrm{C}$ until use for total protein extraction or IFAT (Pinheiro et al. 2005).

Sarcocystis spp. bradyzoites and/or merozoites were obtained from microscopic analysis of myocardium samples from naturally infected cattle and then purified as described by García-Lunar et al. (2015) and then used as antigen (Moré et al. 2011). Briefly, 100g of minced myocardium were mixed with $400 \mathrm{ml}$ of digestion solution $(2.5 \%$ pepsin, $1 \% \mathrm{HCl})$ and were placed in a magnetic stirrer for 20 minutes at $37^{\circ} \mathrm{C}$. The homogenate was filtered using $300 \mu \mathrm{m}$ gauze into a $50 \mathrm{ml}$ tubes and centrifuged at $500 \mathrm{xg}$ for 5 minutes. The supernatant was discarded and the pellet was washed in $30 \mathrm{ml}$ of PBS, $13.5 \mathrm{ml}$ of isotonic Percoll ${ }^{\mathbb{P}}$ (GE Healthcare) and $1.5 \mathrm{ml}$ saline solution $(1.5 \mathrm{M} \mathrm{NaCl})$ and then centrifuged $(4.000 \mathrm{x} \mathrm{g}$ for $10 \mathrm{~min})$ (Pertoft et al. 1980). The supernatants and the upper layer above the pellet were discarded and the pellet was washed three times with PBS to a final concentration of $2 \times 10^{5}$ bradyzoites $/ \mathrm{mL}$. Pellets with bradyzoites were frozen at $-80^{\circ} \mathrm{C}$ until use for total protein extraction or for their use in IFAT (Moré et al. 2008, FernandezGarcía et al. 2009).

IFAT. Slide preparation and IFAT for N. caninum and T. gondii were performed as described by Dubey et al. (1988). Bradyzoites of Sarcocystis spp. were fixed in slides as described by García-Lunar et al. (2015).

In order to investigate antibodies against $N$. caninum and $T$. gondii, serum samples were used at the dilution of 1/64 (Devens et al. 2014) in phosphate-buffered saline solution (PBS; phosphate $0.1 \mathrm{M}, \mathrm{NaCl} 0.33 \mathrm{M}, \mathrm{pH} 7.2$ ). Serum samples were analyzed for antibodies against Sarcocystis spp. in serial dilutions starting at $1 / 10$, dilution in PBS (Tenter 1988). A commercial goat anti-mouse IgG fluorescein isothiocyanate conjugate (Sigma Bio Sciences, St Louis, USA) was used as secondary antibody. Mouse positive and negative sera controls were included on each slide to each parasite. After incubations, slides were observed at $400 \mathrm{x}$ magnification under fluorescent microscope (Leica CTR 4000/EBQ 100, Leica Microsystems, Germany) and complete fluorescence of tachyzoites and bradyzoiytes was considered positive. IFAT were used as a gold standard serologic test, since it presents good sensitivity and specificity to diagnose Sarcocystis spp., N. caninum and T. gondii infections (Moré et al. 2008).

Total protein extraction. Total protein extraction was performed using the Radio-Immunoprecipitation Assay Buffer (RIPA Buffer Sigma Bio Sciences, St Louis, USA) buffer following the manufacturer's recommendations. RIPA Buffer were added $(300 \mu \mathrm{L})$ were added to the pellets containing N. caninum, T. gondii tachyzoites, Sarcocystis spp. bradyzoites, VERO cells and bovine myocardium. The lysate was centrifuged at $8.000 \mathrm{xg}$ for 10 minutes at $4^{\circ} \mathrm{C}$ to sediment the cellular debris. The supernatant containing the protein solution was carefully transferred to a microtube where $3 \mu$ l of protease inhibitor cocktail (Sigma Bio Sciences, St Louis, USA) was added and stored at $-20^{\circ} \mathrm{C}$ until the time of use.

Dot-blot. Nitrocellulose membrane with $0.45 \mu \mathrm{m}$ porosity was used and approximately $12 \mu \mathrm{g} / \mathrm{mL}$ of each parasites purified antigenic protein was distributed. After drying for 20 minutes at room temperature, membranes were washed three times for five minutes under shaking with PBS-T wash solution (0.05\% Tween 20 and PBS) and then blocked with blocking solution (PBS-T with $5 \%$ non-fat dry milk) for 16 hours at $4^{\circ} \mathrm{C}$. Mice serum samples and negative control serum, were diluted $(1 / 50)$ in PBS-T and then distributed on the membrane and incubated at $37^{\circ} \mathrm{C}$ for one hour under slight shaking as previously described (Tenter 1988, Pinheiro et al. 2005). After 
incubation, the membrane was washed three times for five minutes and then incubated with horseradish peroxidase (HRP)-conjugated produced in goat anti-mouse immunoglobulin G (1/2000, Sigma Bio Sciences, St Louis, USA) under shaking for 1 hour at $37^{\circ} \mathrm{C}$. The enzymatic reaction was revealed with a developing solution $(9 \mathrm{~mL}$ of $50 \mathrm{mM}$ Tris-HCl, $1 \mathrm{~mL}$ of $0.3 \%$ Nickel Sulphate, $30 \mu \mathrm{L}$ of Hydrogen Peroxide, $0.006 \mathrm{~g}$ of DAB) (Sigma Bio Sciences, St Louis, USA) for 20 minutes at room temperature (Pinheiro et al. 2005).

\section{RESULTS AND DISCUSSION}

Neospora caninum or Toxoplasma gondii experimentally infected mice tested by IFAT for the 3 protozoans (N. caninum, T. gondii and Sarcocystis spp.) reacted only to $N$. caninum or T. gondii antibodies, respectively. Specific antibodies against Sarcocystis spp. were found in two animals experimentally infected only by this protozoan (one animal showed titer of 50 and other animal presented titer of 800 at IFAT). As previously reported, IFAT is considered the gold standard technique for Sarcocystosis serologic diagnostic in cattle and a positive IFAT result reflects Sarcocystis spp. infection (Garcia et al. 2008, Moré et al. 2008). Therefore, in the present study was established that IFAT would be the standard technique to be compared with Dot-blot test. Moré et al. (2008) have described IFAT at 1:25 dilution to be a suitable method for diagnosis of Sarcocystosis in cattle.

Serum samples from mice experimentally infected with Sarcocystis spp. and tested by Dot-blot demonstrated the presence of antibodies against this protozoan (at 1:50 dilution) but no cross-reactions were observed in the same sample and same dilution against $N$. caninum or T. gondii. Only antibodies against $N$. caninum and no serological crossreactions with T. gondii and Sarcocystis spp. were detected in serum samples from mice inoculated with $N$. caninum. As well as, no cross-reactions against $N$. caninum and Sarcocystis spp. was observed in serum samples from mice infected by T. gondii, showing only specific antibodies against T. gondii. These results showed the Dot-blot sensitivity for coccidian immunological diagnostic in mice and suggest this method as a potential serological test for bovine Sarcocystis spp. detection.

Although there are no studies that indicate the best experimental model for infection with Sarcocystis species that infect cattle, in this study was possible to produce antibodies against Sarcocystis spp. in Mus musculus mice as demonstrated by the two serological diagnostic tests performed. Animals inoculated with Sarcocystis spp. revealed antibodies against this protozoan at Dot-blot technique and showed a high titer of antibodies at IFAT (1:800). Dot-blot proves to be a sensitive test for IgG antibodies against Sarcocystis spp. in this study and similar result was observed by Tenter (1988) in mice infected with Sarcocystis and in agreement with results described by Ndiritu et al. (1996) in experimentally infected bovine. Tenter (1988) compared Dot-blot with the conventional diagnostic methods ELISA and IFAT for serological detection of Sarcocystis muris in immunized and experimentally infected rodents and demonstrated that Dot-blot was sensitive for detection of IgG in immunized mice showing sensitivity equivalent to ELISA and IFAT using serum from infected animals.

The results of the present study suggest that Dot-blot using Sarcocystis spp. antigens present good sensitivity and specificity compared to IFAT and this method should be evaluated using bovine serum samples from naturally infected animals as a possible screening test to detect antibodies against Sarcocystis spp. that could be applied into the field and consequently Dot-blot may be used as an alternative to IFAT, the gold standard technique to bovine Sarcocystosis.

IFAT is a technique that requires expensive equipment as fluorescence microscope is laborious, and difficult to interpret requiring trained technicians (Pappas 1988, Saville et al. 2004). Therefore, diverse serological diagnostic methods have been developed, to make the diagnosis faster and more precise (Moré et al. 2008, Dubey et al. 2015). In addition, the clinical signs of bovine Sarcocystosis when present are non-specific and not always causing visible macroscopic lesions during meat inspection, therefore these serological methods help in infection diagnosis in order to establish disease control measures (Blagojevick \& Antic 2014). Serological tests also allow the diagnosis of N. caninum and T. gondii, in individual or mixed infections (Dubey et al. 1996, Moré et al. 2008). Therefore, Dot-blot may be considered as an alternative specific and sensitive method which makes possible to evaluate a large number of samples into the field in order to facilitate the diagnosis of Sarcocystis infection in cattle herds (Holmdahl et al. 1993, Ndiritu et al. 1996, Guclu et al. 2004). Further studies should be employed allowing the standardization of this method for diagnostic of Sarcocystis spp. in bovine serum samples from naturally infected animals.

\section{CONCLUSION}

Dot-blot showed same specificity and sensibility as IFAT for immunological diagnostic of Sarcocystis spp. in experimentally infected mice and this immunoblot test did not demonstrate serological cross-reactions with Neospora caninum and Toxoplasma gondii.

Compliance with ethical standards.- All experimental practices involving animals were approved by the Ethics Committee for Animal Experimentation at "Universidade Federal de Santa Maria" (UFSM) (Protocol number 87352511).

Conflict of interest statement.- The authors declare that they have no conflict of interest.

\section{REFERENCES}

Akhlaghi M., Razavi M. \& Hosseini A. 2016. Molecular differentiation of bovine sarcocysts. Parasitol. Res. 115(7):2721-2728. <http://dx.doi.org/10.1007/ s00436-016-5020-7> <PMid:27021183>

Blagojevick B. \& Antic D. 2014. Assessment of potential contribution of official meat inspection and abattoir process hygiene to biological safety assurance of final beef and pork carcasses. Food Control 36(1):174-182. <http://dx.doi.org/10.1016/j.foodcont.2013.08.018>

Cawthorn R.J. \& Speer C.A. 1990. Sarcocystis: infections and disease of humans livestock and other hosts, p.91-120. In: Long P.L. (Ed.), Coccidiosis of Man and Domestic Animals. CRC Press Inc., Florida.

Devens B.A., Viloria M.I.V., Silva C.H.S. \& Salcedo J.H.P. 2014. Produção de hibridomas secretores de anticorpos anti- Neospora caninum para uso em imunodiagnóstico. Ciênc. Anim. Bras. 15(2):228-233. <http://dx.doi. org/10.1590/1809-6891v15i223017>

Dubey J.P. 2003. Review of Neospora caninum and neosporosis in animals Korean J. Parasitol. 41(1):1-16. <http://dx.doi.org/10.3347/kjp.2003.41.1.1> <PMid:12666725>

Dubey J.P. 2009. Toxoplasmosis of Animals and Humans. 2nd ed. CRC Press Inc., Florida. 336p. 
Dubey J.P., Calero-Bernal R., Rosenthal B.M., Speer C.A. \& Fayer R. 2016. Sarcocystosis of Animals and Humans. 2nd ed. CRC Press Inc., Florida. 481p.

Dubey J.P., Hattel A.L., Lindsay D.S. \& Topper M.J. 1988. Neonatal Neospora caninum infection in dogs: isolation of the causative agent and experimental transmission. J. Am. Vet. Med. Assoc. 193(10):1259-1263. <PMid:3144521>

Dubey J.P., Howe D.K., Furr M., Saville W.J., Marsh A.E., Reed S.M. \& Grigg M.E. 2015. An update on Sarcocystis neurona infections in animals and equine protozoal myeloencephalitis (EPM). Vet. Parasitol. 209(1/2):1-42. <http://dx.doi.org/ 10.1016/j.vetpar.2015.01.026><PMid:25737052>

Dubey J.P., Lindsay D.S., Adams D.S., Gay J.M., Baszler T.V., Blagburn B.L. \& Thulliez P. 1996. Serologic responses of cattle and other animals infected with Neospora caninum. Am. J. Vet. Res. 57(3):329-336. <PMid:8669764>

Fayer R. \& Dubey J.P. 1986. Bovine sarcocystosis. Compend. Cont. Educ. Pract. Vet. 8:130-142.

Fernandez-García A., Álvarez-Garcia G., Risco-astillo V., Aguado-Martínez A., Marugán-Hernandez V. \& Ortega-Mora L.M. 2009. Patterno f recognition of Besnoitia besnoiti tachyzoite and bradyzoite antigens by naturally infected cattle. Vet. Parasitol. 164(2/4):104-110. <http://dx.doi.org/10.1016/j. vetpar.2009.06.020 > <Mid:19595513>

Gajadhar A.A., Yates E.D.G. \& Allen J.R. 1987. Association of eosinophilic myositis with an unusual species of Sarcocystis in beef cow. Can. J. Vet. Res. 51(3):373-378. <PMid:3115553>

Garcia J.L., Gennari M.S., Navarro I.T., Machado R.Z., Headley S.A., Vidotto O., Guimarães Junior J.S., Bugni F.M. \& Igarashi M. 2008. Evaluation of IFA MAT, ELISAs and immunoblotting for the detection of anti-Toxoplasma gondii antibodies in paired serum and aqueous humour samples from experimentally infected pigs. Res. Vet. Sci. 84(2):237-242. <http://dx.doi. org/10.1016/j.rvsc.2007.04.014> <PMid:17582450>

García-Lunar P., Moré G., Campero L., Ortega-Mora L.M. \& Álvarez-Garcia G. 2015. Anti-Neospora caninum and anti-Sarcocystis spp. specific antibodies cross-react with Besnoitia besnoiti and influence sorological dignosis of bovine besnoitiosis. Vet. Parasitol. 214(1/2):49-54. <http://dx.doi.org/10.1016/j.vetpar.2015.09.011><PMid:26386830>

Guclu F., Aldem-R O.S. \& Güler L. 2004. Differential identification of cattle Sarcocystis spp. by random amplified Polymorphic DNA-Polymerase chain reaction (RAPD-PCR). Rev. Méd. Vét. 155(8/9):440-444.

Holmdahl O.J., Mathson J.G., Uggla A. \& Johansson K.E. 1993. Oligonucleotide probes complementary to variable regions of 18S rRNA from Sarcocystis species. Mol. Cell. Probes 7(6):481-486. <http://dx.doi.org/10.1006/ mcpr.1993.1071> <PMid:8145778>

Moré G., Abrahamovich P., Jurado S., Bacigalupe D., Marin J.C., Rambeaud M., Venturini L. \& Venturini M.C. 2011. Prevalence of Sarcocystis spp. in Argentinean cattle. Vet. Parasitol. 177(1/2):162-165. <http://dx.doi.org/10.1016/j.vetpar.2010.11.036> <PMid:21168276>
Moré G., Basso W., Bacigalupe D., Venturini M.C. \& Venturini L. 2008. Diagnosis of Sarcocystis cruzi, Neospora caninum, and Toxoplasma gondii infections in cattle. Parasitol. Res. 102(4):671-675. <http://dx.doi.org/10.1007/ s00436-007-0810-6><PMid:18066600>

Ndiritu W., Cawthorn R.J., Kibenge F.S.B., Markham R.J.F., Horney B.S. \& Chan C.B. 1996. Use of genomic DNA probes for the diagnosis of acute sarcocystosis in experimentally infected cattle. Vet. Parasitol. 62(1/2):9-25. <http://dx.doi.org/10.1016/0304-4017(95)00852-7><PMid:8638397>

Pappas M.G. 1988. Recent Applications of the Dot-ELISA in immunoparasitology. Vet. Parasitol. 29(2/3):105-129. <http://dx.doi.org/10.1016/03044017(88)90120-3> <PMid:3059666>

Pertoft H., Johnsson A., Warmegard B. \& Seljelid R. 1980. Separation of human monocytes on density gradient of Percoll ${ }^{\circledR}$. J. Immunol. Methods 33(3):221-229. <http://dx.doi.org/10.1016/0022-1759(80)90209-4> <PMid:7373059>

Pinheiro A.M., Costa M.F., Paule B., Vale V., Ribeiro M., Nascimento I., Schaer R.E., Almeida M.A.O., Meyer R. \& Freire S.M. 2005. Serologic immunoreactivity to Neospora caninum antigens in dogs determined by indirect immunofluorescence, western blotting and dot-ELISA. Vet. Parasitol. 130(1/2):73-79. <http:// dx.doi.org/10.1016/j.vetpar.2005.03.018> <PMid:15893072>

Ruas J.L., Cunha C.W. \& Silva S.S. 2001. Prevalência de Sarcocystis spp. (Lankester, 1882) em bovinos clinicamente sadios, da região sul do Rio Grande do Sul, Brasil. Revta Bras. Agrociênc. 7(3):227-230. <http://dx.doi. org/10.18539/CAST.V7I3.402>

Sabin A. 1941. Toxoplasmic encephalitis in children. J. Am. Vet. Med. Assoc. 116:801-814. <http://dx.doi.org/10.14791/btrt.2017.5.1.34> <PMid:28516077>

Saville W.J.A., Dubey J.P., Oglesbee M.J., Sofaly C.D., Marsh A.E., Elitsur E., Vianna M.C., Lindsay D.S. \& Reed S.M. 2004. Experimental infection of ponies with Sarcocystis fayeri and differentiation from Sarcocystis neurona infections in horses. J. Parasitol. 90(6):1487-1491. <http://dx.doi.org/10.1645/ GE-313><PMid:15715250>

Tenter A.M. 1988. Comparison of Dot-ELISA, ELISA and IFAT for the detection of IgG antibodies to Sarcocystis muris in experimentally infected and immunized mice. Vet. Parasitol. 29(2/3):89-104. <http://dx.doi. org/10.1016/0304-4017(88)90119-7> <PMid:3144082>

Tenter A.M. 1995. Current research on Sarcocystis species of domestic animals. Int. J. Parasitol. 25(11):1311-1330. <http://dx.doi.org/10.1016/00207519(95)00068-d> <PMid:8635883>

Uggla A., Hiali M. \& Lovgren K. 1987. Serological responses in Sarcocystis cruzi infected calves challenged with Toxoplasma gondii. Res. Vet. Sci. 43(1):127-129. <PMid:3114848> 